цевта 3 метою одержання необхідної консультації стосовно вибору та застосування лікарського засобу. Тому до найбільш загальних професійних компетенцій фармацевтів можна віднести: знання, вміння й навички 3 професійної діяльності; комунікативні вміння і навички, здатність вести бесіду, спілкуватись 3 відвідувачами аптечних закладів. Кращою оцінкою рівня професійної компетентності є праце- влаштування випускників, яке значною мірою залежить від їх конкурентоспроможності. Це означає, що конкурентоспроможність - результат професійної компетентності. А розширення можливостей працевлаштування громадян, зростання міжнародної конкурентоспроможності європейської вищої освіти, побудова європейського простору вищої освіти є суттю основних положень Болонської декларації.

УДК $614.2(07)$

\title{
ВПРОВАДЖЕННЯ СУЧАСНИХ ФОРМ ОРГАНІЗАЦІЇ НАВЧАННЯ У ПРАКТИКУ ПІСЛЯДИПЛОМНОЇ ОСВІТИ
}

\author{
О. С. Никоненко, С. Д. Шаповал, С. М. Дмитрісва \\ Запорізька медична академія післядипломної освіти
INTRODUCTION OF MODERN ORGANIZATIONAL FORMS OF STUDY IN POST-GRADUATE EDUCATION

\author{
O. S. Nykonenko, S. D. Shapoval, S. M. Dmytriyeva \\ Zaporizhian Medical Academy of Post-Graduate Education
}

\begin{abstract}
У статті представлено досвід впровадження в післядипломну підготовку медичних спеціалістів нових сучасних форм організації навчального процесу у Запорізькій медичній академії післядипломної освіти. Висвітлено деякі проблемні питання розробки та впровадження нових організаційних форм навчання та сучасних освітніх технологій у післядипломній підготовці лікарів. Обгрунтована необхідність застосування різних організаційних навчальних форм 3 використанням технологій активного навчання відповідно до потреб кожної цільової групи суб' сктів навчання.
\end{abstract}

Some questions of problems in relation to introduction of new organizational educational forms at post-graduate education of medical specialists at Zaporizhian Medical Academy of Post-Graduate Education are considered by authors in the article. The problem of development and introduction of new organizational forms of training and modern educational technologies in postgraduate education of doctors are discussed in the article. Necessity of forming of flexible system of post-graduate education of doctors with introduction of different organizational forms and modern technologies of active studies according to requirements of each target group of subjects of training are proved.

Вступ. Концепція реформування системи вищої медичної освіти України має стратегічною метою приведення iii у відповідність до європейських вимог за міжнародними освітніми стандартами [1]. Задачею сучасного етапу освітньої реформи $\epsilon$ впровадження у післядипломну підготовку лікарів інноваційних освітніх технологій 3 переглядом традиційних конструкцій організації навчання, які вже не забезпечують мотивації суб' єктів навчання до безперервного професійного розвитку. Використання нових підходів до організації медичної освіти має за мету впровадження в педагогічну практику принципів сучасного клінічного навчання, доказової медицини, біоетики та клініко-економічних стандартів 3 найбілыш медико-соціально значимих нозологій відповідно до міжнародного досвіду на підставі поглиблення практичної спрямованості занять та удосконалення технічних засобів навчання. Тому розробка та апробування нових організаційних форм і методів підготовки медичних фахівців є вимогою часу та умовою успішності освітньої діяльності сучасних медичних ВНЗ післядипломної освіти $[2,3]$.

Основна частина. Головним принципом організації освітньої діяльності Запорізької медичної академії післядипломної освіти є практична спрямованість навчання з урахуванням потреб практичної охорони здоров'я, орієнтація на світові досягнення, впровадження в педагогічний процес новітніх, зокрема, комп'ютерних і телемедичних технологій навчання та контролю знань із збереженням позитивних особливостей національної системи медичної освіти [4]. 
На виконання завдань освітньої реформи в академії впроваджуються інноваційні навчальні технології та сучасні форми підготовки лікарів (дистанційне навчання, телемедичні технології, організація інтенсивної підготовки лікарів на короткотривалих циклах інформації та стажування, забезпечення безперервного навчання на постійно діючих проблемних семінаpax 3 максимальною відповідністю змісту навчання реальним умовам роботи лікарів). 3 метою визначення оптимальних підходів щодо впровадження нових організаційних форм навчання в академії здійснюється моніторинг з узагальнення та аналізу досвідузастосування інноваційних освітніх технологій у педагогічній практиці. На даний час сформований пакет пропозицій ЗМАПО щодо забезпечення гнучкості навчання в регламентованих термінах та організаційних формах традиційних циклів підготовки лікарів (спеціалізація, тематичне удосконалення, стажування). В академії реалізується програма впровадження дистанційного навчання у підготовку лікарів. Дистанційні технології використовуються в реалізації проекту зі створення і функціонування системи самонавчання викладачів, контактно-дистанційні технології застосовуються при організації циклів удосконалення лікарів за кейс-, TV-, мережевими або технологіями мобільного Інтернету [5].

На кафедрах ЗМАПО здійснено опрацювання навчального матеріалу за модульними технологіями, що дає можливість формування гнучкого графіка організації занять. В академії розроблена та апробується методика проведення інтенсивного курсу інформації та стажування 3 майстер-класом, який складається з дистанційного (підготовчого) та очного (практичного) модулів. Впровадження короткотривалих курсів інформації та стажування має за мету оптимізацію викладання з цільовим відпрацюванням медичних технологій згідно з принципом відповідності змісту навчання реальним умовам роботи практичних лікарів.

\section{Література}

1. Про затвердження Концепції розвитку вищої медичної освіти України : наказ Міністерства охорони здоров'я і Академії медичних наук України № 522/51 від 12.09.2008 p.

2. Про удосконалення післядипломної освіти лікарів : наказ Міністерства охорони здоров’я України № 1088 від 10.12.2010 p.

3. Про затвердження змін до положення про проведення іспитів на передатестаційних циклах : наказ Міністерства охорони здоров'я України №484 від 07.07.2009p.

4. Система управління якістю медичної освіти в Україні / [І. С. Булах, О. П. Волосовець, Ю. В. Вороненко та ін.]. - Д. : АРТ-ПРЕС, 2003.-212 c.
У форматі переривчастих курсів тематичного удосконалення в ЗМАПО впроваджена нова організаційна форма професійного розвитку лікарів - постійно діючі проблемні семінари. Пріоритетною цільовою групою таких семінарів $€$ лікарі первинної ланки медико-санітарної допомоги. Тематичний зміст занять обирається згідно з пріоритетами Національногоплану дій з реформування галузі охорони здоров'я. Організаційна структура побудована за модульним принципом іпередбачає проведення тематичних занять (конференції, майстеркласи, лекції, семінари, круглі столи тощо), а також надання консультативної та організаційно-методичної допомоги закладам практичної охорони здоров'я. За результатами технічної оцінки зворотного зв' язку з учасниками навчання інформаційна насиченість іпрактична спрямованість дозволяють оцінити постійно діючі проблемні семінари як перспективну форму безперервного професійного розвиткулікарів [6].

Висновки: 1. Складовою завдань освітньої реформи в Україні є приведення системи підготовки медичних фахівців у відповідність до міжнародних освітніх стандартів, у тому числі за сучасними організаційними формами і технологіями навчання, з використанням позитивних рис європейських освітніх моделей.

2. Забезпечення безперервного підвищення кваліфікаційного рівня медичних спеціалістів вимагає диференційованої оцінки організаційних форм навчання.

3. Впровадження інноваційних освітніх технологій (майстер-класи, контактно-дистанційне навчання) в межах традиційних організаційних форм післядипломної підготовки лікарів сприяє підвищенню мотивації до активної участі в навчанні.

4. Розробка та апробування нових організаційних форм безперервного професійного розвитку лікарів вимагають впровадження в педагогічну практику принципів сучасного клінічного навчання, доказової медицини, біоетики та клініко-економічних стандартів 3 найбільш медико-соціально значимих нозологій відповідно до міжнародного досвіду.

5. Питання розробки нормативів дистанційного навчання в післядипломній медичній освіті / Ю. В. Вороненко, О. П. Мінцер, Ю. П. Вдовіченко [та ін.] // Медична інформатика та інженерія. -2008. - № 3. - С. 58-68.

6. Никоненко О. С. Проблемні питання впровадження безперервного професійного розвитку лікарів на етапі реформування системи вищої медичної освіти / О. С. Никоненко, С. Д. Шаповал, С. М. Дмитрієва // Медична освіта. 2007.-№4. - С.4-6. 